\title{
ORGANIC GRAIN PRODUCTION MARKET OF UKRAINE: PROSPECTS AND TRENDS
}

\author{
Viktoriia BONDAR ${ }^{1}$ \\ Odessa National Academy of Food Technologies, Ukraine
}

\begin{abstract}
The purpose of the paper is to determine the prospects of the market of organic products in Ukraine. The article studies the market for organic produce dynamic area of organic farmland, number of organic farms in volume production of organic products. Identified key factors influencing the market for organic products Ukraine, outlined areas of the market based on its current state. Grain industry serves as a source of sustainable development of agriculture, determines the socio-economic condition of society and is the basis of agricultural exports. Therefore, the development of the organic market of grain and its products are of particular importance and led to the goal and objectives of bottom investigation. Methodology. The theoretical and methodological basis of the study are works of economists on the development of ecology management, general scientific methods and approaches in the field of business management: historical, dialectical, abstract logical methods of system-structural analysis and synthesis of scientific research and provision of economic theory, management. Results. Proved that Ukraine has considerable potential as a producer of agricultural products, including organic farming, export, consumption in the domestic market. To determine the market trends of organic products studied the dynamics of agricultural surfaces of Ukraine, reserved for growing organic products. To further study the characteristics and trends of the market for organic products in Ukraine, examined the dynamics of the number of organic farms. For determining the main trends and the prospects of the organic products market, and in addition for researching proposals, examined demand for market research of market demand for organic products in terms of production of organic products in Ukraine. Practical implications. The main problem of Ukraine of organic production is exported domestic products as organic production of agricultural products. Analysis of key market trends of organic products allowed coming to the conclusion that the market is developing and if current trends continue, it will lead to its development in the future; however, organic market Ukraine is now at the initial stage of development over the lack of effective legislative framework for regulation areas of organic production. Value/originality. So, for proper legal regulation and implementation of a balanced policy towards organic production, namely uniform requirements and rules for organic production, unified system of certification, certification and labeling of organic products will increase growth of organic products market and it ranks will high in the food security of Ukraine, and with the agricultural potential of the country Ukraine will reach the leading position in the global market of organic products.
\end{abstract}

Key words: organic products, organic market, organic production, organic production prospects in Ukraine

JEL Classification: L66, O13, Q1

\section{Introduction}

Grain is one of the mostimportant sources of wealth ofany state. In the global agriculture and in Ukraine grain always dominated and now grain has a special place in agricultural production as guarantee of food safety value of grain production as a strategic industry predetermined constant supply and high demand of people in the consumption of foods made from grains. Grain industry serves as a source of sustainable development of agriculture, determines the socio-economic condition of society and is the basis of agricultural exports. Therefore, the development of the organic market of grain and its products are of particular importance and led to the goal and objectives of this investigation. In the issues of development of the market of organic products in Ukraine are engaged scientists: V. Artysh, N. Zinovchuk, O. Rudnytska, P. Skrypchuk, T. Seagull, G. Shevchuk, I. Sedikova and E. Korenman, who analyzed the performance evaluation of organic production. The economic performance of organic farms authors studied on the example of winter wheat and spring barley. However requires further study on the functioning and establishment of market organic grain production. The main goal of this study is to determine the prospects of the market of organic products in Ukraine.

Corresponding author:

${ }^{1}$ Department of Management and Logistics, Odessa National Academy of Food Technologies.

E-mail: kaf-ml@mail.ru 


\section{Presenting main material}

According to the International Federation of Organic Movement, the total turnover of organic products worldwide reached $60 \mathrm{bln}$. dollars, the total area of land used for organic production reached almost 37 million. ha and the total number of employees - 1.8 million farmers. Leaders of organic production were the US (26,8 billion dollars), Germany (7,9 billion dollars), France (4,5 billion dollars).

Ukraine has significant potential as a producer of agricultural products, including organic farming, export and consumption in the domestic market because its territory of agricultural land area is about 42,4 million ha. Thus, the area of organic farmland in Ukraine is about 270 thousand hectares, their share in total agricultural land is about $0,7 \%$ organic products. However, the market of organic production in Ukraine is still in its infancy over the lack of existing normative acts regulating the field of organic production, which does not contribute to its development.

To determine the market trends of organic products: To study the dynamics of agricultural lands of Ukraine, reserved for growing organic products (Fig. 1).

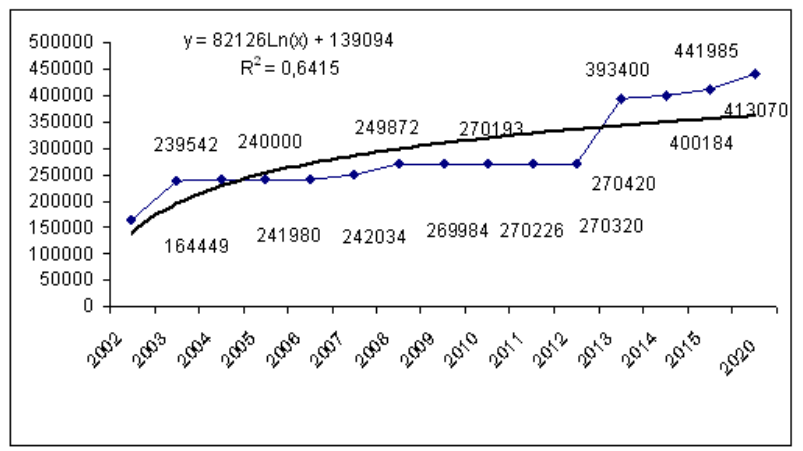

Fig. 1. Dynamics of the area of organic farmland in Ukraine, ha Source: Author is built according to the Organic Federation of Ukraine

During 2002-2012 years there was a steady upward trend in the area of organic farmland in Ukraine. Based on sample data for 2002-2015 years is built logarithmic trend in the area of organic farmland in Ukraine. The correctness of the applied model is confirmed by a high value of coefficient of determination, which is 0,64 . The trend shows that if current trends continue dynamics of organic

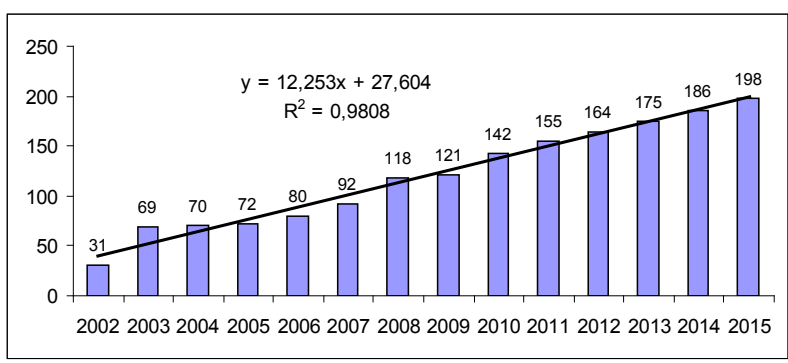

Fig. 2. Changes in the number of organic farms in Ukraine

Source: Built by the author according to the Organic Federation of Ukraine farmland, their area will continue to increase. To further study of the characteristics and trends of the market for organic products Ukraine, the dynamics of the number of organic farms is considered (Fig. 2).

From 2002 to 2015 the number of organic farms is increasing. So in 2002, 31 were functioning enterprises, in 2015 - 164 organic farms. Based on sample data for 20022015 years is built a linear trend of the number of organic farms in Ukraine. The correctness of the applied model is confirmed by a high value of coefficient of determination, which is 0,98 . The trend shows that if current trends continue dynamics of organic farms Ukraine, their number will continue to grow.

Compared the growth of organic farmland area and the number of organic farms with the aim of deeper trends of the organic products market of Ukraine (Fig. 3).

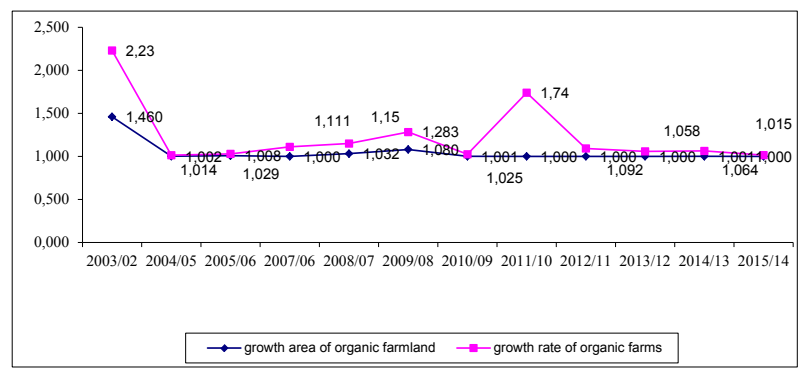

Fig. 3. Growth rates of organic agricultural land area and number of organic farms in Ukraine

Source: Built by the author according to the Organic Federation of Ukraine

During the study period growth rate of organic farms exceeds the growth of area of organic farmland that can be indicated by the following:

- newly organic farms are generally small companies that grow organic production in a small area, which are slightly enrich the basic foundation of organic farmland;

- slight increase in area of organic farmland in comparison with the big increase in the number of organic farms can indicate a certain redistribution of the market in this area; - in the same time, a slight increase in area under cultivation of organic products and the growing number of organic farms can indicate intensive processes as closing and opening of businesses in this area.

For isolating the main trends and determining the prospects of the organic products market, in addition to research proposals should be explored market demand study showing market demand for organic products made in terms of production of organic products in Ukraine (Fig. 4). The volume of organic products is growing, so in 2006 the market volume was 250 thousand euros, in 2015 it is 8,25 million euros. Based on sample data for 2006-2015 years there is built exponential trend in production of organic products in Ukraine. The trend shows that if current trends continue dynamics of organic products of Ukraine, its volume will continue to grow. 


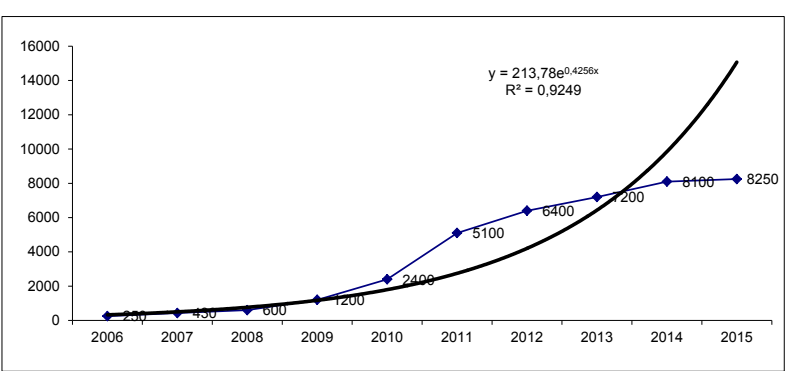

Fig. 4. Dynamics of production of organic products of Ukraine for 2006-2015

Source: Built by the author according to the Organic Federation of Ukraine

Based on the comparison of growth area of organic farmland, number of organic farms and production of organic products in Ukraine for 2006-2015 years the following conclusions are made: growth in production of organic products is much higher than the growth rate of the area under organic farmland and the number of organic farms, indicating increase in the number of organic consumers, increasing demand for organic products in foreign markets and annual price increase for these products. Given the absence of a significant increase in the number of organic farms, the emergence of own brands or manufacturers that produce organic products, there is likely higher prices for organic products with increasing demand and lack of supply growth.

The organic movement in Ukraine involved: Organic Federation of Ukraine, Association «Pure Flora» Association «Poltava Organic», International Public Association of Organic Production Stakeholders $\ll$ BIOLan Ukraine», Club of organic farming, the Union of Organic Agricultural Production «Naturprodukt», the Organic standard of «Ukragrofin», Ukrainian public organization «Living Planet». The majority of organizations position themselves as members of the organic movement in Ukraine perform services certification and labeling of organic products and are members of internationally recognized organizations: Global Ecolabelling Network (GEN) and International Federation of Organic Agriculture Movement (IFOAM).

Ukrainian public organization «Living Planet» is a member of Global Ecolabelling Network (GEN), a member of the International Federation of Organic Agriculture Movement (IFOAM), which includes the Organic Federation of Ukraine, Public Association of Organic Production Stakeholders «BIOLan Ukraine» Organic Standard, LLC «Ukragrofin» which are based on associate membership of Ukrainian public organization «Living planet». Main market operators, service providers and certification of organic farms capture the rapid development of the market for organic products and high potential development. However, based on the dynamics of the processes of the area under cultivation of organic products and the number of organic farms, we can conclude that the organic market is only in its infancy and its growth rates are negligible. It should be noted that all organizations involved in the research market for organic products and the development of organic production, regardless of whether they are members of international organizations supporting organic production or operating in the domestic market, providing services and certification of products as organic. Accordingly, a certain degree of research on the development and prospects of the organic products market is subjective.

Today in Ukraine there are no existing regulations that determine what kind of products are products of organic production, which organizations can provide certification of organic products, certification procedure for organic products and certification institutions have the right to implement it and what kind of labeling is apply to organic products. At the same time according to the draft Law «On the Production and Turnover of Organic Agricultural Products and Raw Materials $\gg$ number 979 on 12/12/2012, the «organic product - a product obtained from the production certified according to the requirements». Common to all types of organic products under the Law are methods and requirements for organic production. The need for a single state labeling project is included to the Law «On the Production and Turnover of Organic Agricultural Products and Raw Materials» number 979 on $12 / 12 / 2012$, which states that «the use of the state logo and labeling of organic products to indicate organic products is a necessity». However, while indicating the need for a state the drafted law "permitted the use of nongovernment (private) logos introduced directly to entities engaged in the production, sale of organic products, raw materials or their associations."

The main directions of development of the organic products are contained in the State program of organic production in Ukraine. The criterion for the success of the program will be value of the share of land under organic production as a percentage of the total agricultural land of the country.

During the implementation of the program planned to achieve the following indicators (percentage of land certified by organic farms) should be: the end of 2012 $2 \%$; by the end of $2020-7 \%$. As of year 2012 planned program indicators have not been fulfilled, there is the need to develop a mechanism for achieving results.

Leaders of organic agricultural production in Ukraine is $\mathrm{PE}$ «Agroecology» (Poltava region), the group of companies «Etnoprodukt» (Chernihiv region), LLC «Haleks-Agro» (Zhytomyr region), «Organic farming «Maharishi»» (Kherson and Mykolaiv regions), PE «Miller» (Vinnytsia region), LLC «Clean product-C» (Donetsk region) and many others. High profitability of organic agroproducts for small volume production is explained by higher prices of organic products implementation. Despite unformed demand and unexecuted target audience, product prices on organic production have always been higher than the prices on the products of conventional production method. Similar 
findings also demonstrate the performance of farm enterprise «Otradivske» of Odessa region, which grows organic agricultural products. Thus, comparing the cost of organic production in the above sector averages and data on agricultural area in 2013 (Table 1), it should be noted that only the production of spring barley production costs for organic technology exceed the average cost of holdings (by $8,51 \%$ ).

Table 1

Production cost of $1 \mathrm{~kg}$ of crops for conventional and organic production technology in Odessa region

\begin{tabular}{|c|c|c|c|c|}
\hline \multirow[b]{2}{*}{ Culture } & \multirow{2}{*}{$\begin{array}{c}\mathrm{FE} \\
\ll \text { Otradivske» }\end{array}$} & \multirow{2}{*}{$\begin{array}{c}\text { On average, } \\
\text { the district } \\
\text { UAH }\end{array}$} & \multicolumn{2}{|c|}{ Deviation } \\
\hline & & & $\begin{array}{c}\text { absolute, } \\
\text { UAH }\end{array}$ & $\begin{array}{c}\text { relative, } \\
\%\end{array}$ \\
\hline $\begin{array}{l}\text { Winter } \\
\text { wheat }\end{array}$ & 92,0 & 113,58 & 21,58 & 7,36 \\
\hline $\begin{array}{l}\text { Heads } \\
\text { boring }\end{array}$ & 130,0 & 118,94 & $-11,06$ & $-8,51$ \\
\hline Soy & 156,45 & 208,86 & 52,41 & 33,50 \\
\hline Buckwheat & 75,02 & 279,92 & 204,9 & 273,13 \\
\hline
\end{tabular}

Cost of production of $1 \mathrm{~kg}$ of organic winter wheat, soy and buckwheat are significantly lower the cost of production of these products by traditional technology. Overall, the ratio of production cost of traditional products and organic production in Ukraine differs by product. These findings confirm and research U. Gavaza in 2012, among the crops is studied only the production cost of organic winter rye, oats and vegetables open ground instead of the cost of production of these crops on conventional technology (Gavaza, 2014). In other cultures organic production costs are much lower.

According to the research market for organic products, organic grain prices depending on quality and demand, exceed the price of the traditional zero production by 50-200\%, while prices of fruits and vegetables - by $20-100 \%$. Today, the world price of wheat tons (under FOB) is about $\$ 180$, barley $-\$ 140$. The status of $\ll$ organic products $\gg$ price increases respectively to 252 and 196 dollars per tonne (Potapenko, 2011).

Today Ukraine is at the third stage of the market of organic foods - market. Developed network marketing of organic products: organic shops opening («Natur Boutique», Kyiv), inclusion of organic foods in domestic supermarkets range («Bill», «Metro», «West Line»). During the year the number of stores of organic products has tripled and reached 60. A growing number of organic certified raw materials and processing organizations («Step» SPD «Ishchuk», LLC «KDP Wise» Canning plant Illinetskyi NDH, LLC «Cereal House», Ltd. «Grinding house» and others) has established a number of environmentally friendly production of cereals under TM «Handful» of the BIOLan. Also, with the efforts of the Marketing Department of the association were sold 4.5 tons of clean vegetables. Out of environmentally friendly products of BIOLan on the shelves of Ukrainian stores it contributed to the fact that the standards «BIOLan» passed one of the largest organic farms in Ukraine - 1111 «Agroecology» (8300 ha, ca.) and the Vedic Organic Agriculture «Maharishi» (40 000 ha, Kherson region). Today another 180 households are willing to join the organic movement and organic foods grown without the use of chemicals (Bulletin of the Association «BIOLan Ukraine», 2013). Among the well-known domestic brands of organic foods are TM «Hercules», «Mr. Eko» (the first domestic producer of organic jams), TM «Handful» (organic cereals). Certified environmentally friendly products, represented at international exhibitions European Ukrainian companies - a grain, dried / frozen berries, herbs, teas, mushrooms, cereals, vegetables (cabbage, carrots, potatoes, beets). Research of the demand for organic food shows that about $70 \%$ of potential customers are familiar with the environmentally friendly production of food, but it meant by products grown in gardens and gardens of individual households that do not undergo industrial processing. After the explanation of the term «organic food» all without exception respondents agreed to pay them a higher price, subject to availability of quality assurance, while $36,8 \%$ agreed to pay for it in 1,5-2 times more than for conventional products. For $72,6 \%$ of consumers such as the guarantee can be appropriate certified sign. Several consumers (5,3\%) expressed doubts about the possible existence of environmental cleanliness products guarantee in general (Zaichuk, 2015). The data also confirmed by studies conducted in other regions (Schapak, 2014). The main consumers, unlike the stereotypical idea about availability of organic products only to wealthy people, are young mothers or those who are preparing to become them; students who profess the idea of healthy eating and retirees who prefer more expensive, but more healthy and useful product. It should be noted that the solvent buyers are concentrated mainly in large cities. The main competitors of ecologically clean food products are, first, the conventional products now sold in stores and market, the quality of which (mainly in terms of safety) is questionable. Secondly, certified imported organic products that have appeared in a number of supermarkets and have indisputable advantage - tested certified mark that guarantees the ecological purity of the product, all of its components, raw materials, processing technology and packaging. Done in Poltava region attempt to ensure that consumer demand for organic foods labeled product of domestic production, carried out under the project «in harmony with nature» was not successful, mainly over the fact that producers had to bear additional costs for «ecologically clean and safe» trademark advertising of their products, to inform consumers about the benefits of clean food products and the safeguards provided by this sign, and so on. Farms not profitable to switch to organic methods of management offset additional costs by additional benefit where it is possible.

Strategy to ensure the competitiveness of organic foods domestic production in the domestic market should be 
based on the chances offered by today. This should take the following steps. First, we should establish environmentally friendly raw materials processing, because the processing plants is mixed with another, as finished products domestic food production is not environmentally friendly. The solution to this problem is possible by adjusting for farm enterprises complete production cycle, which makes it possible to manufacture finished products, primarily milk and meat, which exists in the world's largest deficit, and in Ukraine they never started production.

Second, the full production cycle will reduce the cost of finished organic foods and will meet the social demand for them to master this consumer segment, the market organizations, as hospitals and other health institutions, school and pre-school institutions, by reason of their financing and procedures tender procedures have to buy up food at the lowest price subject to compliance with existing quality standards. In a crisis, to establish a system of state subsidies for organic producers and promote the usefulness of organic products at the national level is almost impossible. Providing producers of organic foods with any tax benefits in imperfect tax legislation needed to be changed is too very problematic. But now profitable to attract investment, and developed Asian countries are ready to implement a profitable investment. Production of organic foods in Ukrainian black soil involves technology investor refers specifically to them. Formation of economically-economic mechanism of implementation of complete production cycle in farms, studying ways to implement and defining the role of the state in this process are the tasks of further research in this direction.

\section{Conclusions and suggestions}

The main problem of organic production market in Ukraine is exported domestic products as organic production of agricultural products. Analysis of key market trends of organic products allowed coming to the conclusion that the market will develop if current trends continue its development in the future; however, organic market Ukraine is now at the initial stage of development over the lack of effective legislative framework for regulation areas of organic production. So, for proper legal regulation and implementation of a balanced policy towards organic production, namely uniform requirements and rules for organic production, unified system of certification, certification and labeling of organic products will increase growth of organic products market and it ranks high in the food Ukraine's security, and with the agricultural potential of the country Ukraine will reach the leading position in the global market for organic products.

\section{References}

Gavaza, U. V. (2014, May). Marketplace orhanycheskoy production and infrastructure ego: Modern status and prospects of development. AIC economy, 5, 131 .

Potapenko, V. G. (2011, May). Organic agriculture as a factor of economic security. AIC economy, 5, 58-65.

Zaichuk, T. O. (2015, April). Assessment of demand for organic food. Aspects of sustainable economic development, 4, 150-152.

Bulletin of the Association «BIOLan Ukraine» (2013). Retrieved from: http://www.biolan.org.ua/download. php? articleid=2

Bulletin of the Association «BIOLan Ukraine» (2014). Health Watch - «BIOLan Ukraine» Retrieved from: http://a7d.com.ua/1284-na-varti-zdorovya-biolan-ukrayina.html.

Schapak, V. O. (2014, March). On the cultivation of environmentally friendly vegetable production in Ukraine. Modern trends in production and marketing of organic products, 3, 30-33.

\section{Виктория БОНДАРЬ}

\section{РЫНОК ОРГАНИЧЕСКОГО ЗЕРНОПРОИЗВОДСТВА УКРАИНЫ: ПЕРСПЕКТИВЫ И ТЕНДЕН- ЦИИ РАЗВИТИЯ}

Аннотация. Целью работы является определение перспектив рынка органических продуктов в Украине. В статье проведено исследование тенденций развития рынка органических продуктов в разрезе сельскохозяйственных площадей, количества органических хозяйств, объемов производства органических продуктов. Выявлены ключевые факторы, влияющие на рынокорганическихпродуктов Украины, предложены направления развития рынка. Зерновой рынок служит источником устойчивого развития сельского хозяйства, определяет социально-экономическое состояние общества и является основой экспорта. Таким образом, развитие органического рынка зерна и продуктов его переработки имеют особое значение и определило цели и задачи данного исследования. Методика. Теоретической и методологической базой исследования стали работы экономистов в области экологического менеджмента и управления бизнесом: исторические, диалектические, абстрактные логические, методы анализа и синтеза, системного похода к научным исследованиям. Результаты. Доказано, что Украина имеет значительный потенциал в производстве сельскохозяйственной продукции, в том числе органической, экспорта, потребления на внутреннем рынке. 
Для определения тенденций рынка органических продуктов изучена динамика сельскохозяйственных площадей Украины, отведенных для выращивания экологически чистых продуктов. Исследована динамика развития органических предприятий. Исследован спрос и предложения на органические продукты. Практическое значение. Анализ основных тенденций на рынке органических продуктов позволили прийти к выводу, что рынок находится на начальной стадии развития, в связи с отсутствием эффективной законодательной базы для регулирования областей органического производства. Значение/оригинальность. Сделанные выводы и предложенные мероприятия позволят реализовать сбалансированную политики в отношении органического производства и занять лидирующие позиции на мировом рынке органических продуктов. 